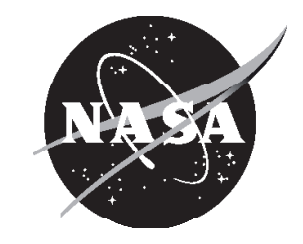

\title{
Experimental Evaluation of Stagnation Point Collection Efficiency of the NACA 0012 Swept Wing Tip
}

Jen-Ching Tsao

Ohio Aerospace Institute, Brook Park, Ohio

Richard E. Kreeger

Glenn Research Center, Cleveland, Ohio 


\section{NASA STI Program . . . in Profile}

Since its founding, NASA has been dedicated to the advancement of aeronautics and space science. The NASA Scientific and Technical Information (STI) program plays a key part in helping NASA maintain this important role.

The NASA STI Program operates under the auspices of the Agency Chief Information Officer. It collects, organizes, provides for archiving, and disseminates NASA's STI. The NASA STI program provides access to the NASA Aeronautics and Space Database and its public interface, the NASA Technical Reports Server, thus providing one of the largest collections of aeronautical and space science STI in the world. Results are published in both non-NASA channels and by NASA in the NASA STI Report Series, which includes the following report types:

- TECHNICAL PUBLICATION. Reports of completed research or a major significant phase of research that present the results of NASA programs and include extensive data or theoretical analysis. Includes compilations of significant scientific and technical data and information deemed to be of continuing reference value. NASA counterpart of peer-reviewed formal professional papers but has less stringent limitations on manuscript length and extent of graphic presentations.

- TECHNICAL MEMORANDUM. Scientific and technical findings that are preliminary or of specialized interest, e.g., quick release reports, working papers, and bibliographies that contain minimal annotation. Does not contain extensive analysis.

- CONTRACTOR REPORT. Scientific and technical findings by NASA-sponsored contractors and grantees.
- CONFERENCE PUBLICATION. Collected papers from scientific and technical conferences, symposia, seminars, or other meetings sponsored or cosponsored by NASA.

- SPECIAL PUBLICATION. Scientific, technical, or historical information from NASA programs, projects, and missions, often concerned with subjects having substantial public interest.

- TECHNICAL TRANSLATION. Englishlanguage translations of foreign scientific and technical material pertinent to NASA's mission.

Specialized services also include creating custom thesauri, building customized databases, organizing and publishing research results.

For more information about the NASA STI program, see the following:

- Access the NASA STI program home page at http://www.sti.nasa.gov

- E-mail your question via the Internet to help@ sti.nasa.gov

- Fax your question to the NASA STI Help Desk at $443-757-5803$

- Telephone the NASA STI Help Desk at 443-757-5802

- Write to: NASA Center for AeroSpace Information (CASI) 7115 Standard Drive Hanover, MD 21076-1320 


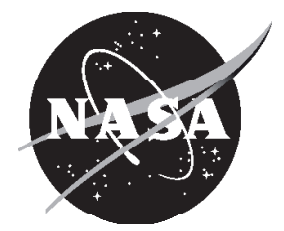

\section{Experimental Evaluation of Stagnation Point Collection Efficiency of the NACA 0012 Swept Wing Tip}

Jen-Ching Tsao

Ohio Aerospace Institute, Brook Park, Ohio

Richard E. Kreeger

Glenn Research Center, Cleveland, Ohio

Prepared for the

1st Atmospheric and Space Environments Conference

sponsored by the American Institute of Aeronautics and Astronautics

San Antonio, Texas, June 22-25, 2009

National Aeronautics and

Space Administration

Glenn Research Center

Cleveland, Ohio 44135 


\section{Acknowledgments}

The authors wish to thank Mario Vargas of the NASA Glenn Icing Branch for his support of this work, and the NASA Glenn Icing Research Tunnel (IRT) personnel for their excellent and committed technical support.

This report contains preliminary findings, subject to revision as analysis proceeds.

Level of Review: This material has been technically reviewed by technical management.

Available from

NASA Center for Aerospace Information 7115 Standard Drive

Hanover, MD 21076-1320
National Technical Information Service 5301 Shawnee Road Alexandria, VA 22312

Available electronically at http://gltrs.grc.nasa.gov 


\title{
Experimental Evaluation of Stagnation Point Collection Efficiency of the NACA 0012 Swept Wing Tip
}

\author{
Jen-Ching Tsao \\ Ohio Aerospace Institute \\ Brook Park, Ohio 44142 \\ Richard E. Kreeger \\ National Aeronautics and Space Administration \\ Glenn Research Center \\ Cleveland, Ohio 44135
}

\begin{abstract}
This paper presents the experimental work of a number of icing tests conducted in the Icing Research Tunnel at NASA Glenn Research Center to develop a test method for measuring the local collection efficiency of an impinging cloud at the leading edge of a NACA 0012 swept wing and with the data obtained to further calibrate a proposed correlation for such impingement efficiency calculation as a function of the modified inertia parameter and the sweep angle. The preliminary results showed that there could be some limitation of the test method due to the ice erosion problem when encountered, and also found that, for conditions free of such problem, the stagnation point collection efficiency measurement for sweep angles up to $45^{\circ}$ could be well approximated by the proposed correlation. Further evaluation of this correlation is recommended in order to assess its applicability for swept-wing icing scaling analysis.
\end{abstract}

\section{Introduction}

The results presented here are part of an effort to develop scaling methods for swept wing ice accretion. Previously, Anderson (Ref. 1) has completed a NASA report that gives a detailed technical review of recommended scaling methods for ice accretion on unprotected, unswept aerodynamic surfaces in Appendix C condition. Later, Anderson and Tsao (Ref. 2) have further supplemented the Appendix C studies of Reference 1 with recent data from both SLD and Appendix C tests.

It was concluded from those two references that acceptable scaling results could be achieved by matching the $\beta_{0}, A_{c}, n_{0}$ and $\mathrm{We}_{L}$. With scale model size selected, by matching scale and reference values of $\mathrm{We}_{L}$ the scale velocity can be determined. By matching $\beta_{0}$ the scale $M V D$ can be found. Reference 1 also showed that the effects of temperature and $L W C$ are not independent, but interact through the freezing fraction. Therefore, with scale $L W C$ chosen, by matching $n_{0}$ the scale temperature can be calculated. Finally, by matching $A_{c}$ the scale time can be established. For the scale test, then, only temperature, velocity, $M V D$ and time have to be calculated from the known (Reference) values of the similarity parameters.

While some of these similarity parameters are based on conditions that apply anywhere on the model, $\beta_{0}$ and $n_{0}$ are specific to the stagnation line of a clean model. Therefore, strictly speaking, scaling methods only apply at the stagnation line of a clean model. These parameters vary with chord-wise location and change as ice accretion modifies the geometry. Consequently, two assumptions are implied for scaling to be valid. The first is that with similar model geometries and similar flows around both reference and scale models, if $\beta$ and $n$ match at the stagnation point, they will tend to match everywhere on the model. This assumption has been verified for collection efficiencies in Figure 1(b) of Reference 2. As for other airflow related issues: transition and roughness, for example, may not scale, and Re effects are assumed to have a minor influence on the final ice shape. Second, if the scaling is done successfully, the scale ice shape normalized by the model size will consistently agree with the reference for any accretion time starting 
with the clean model. Therefore, scale $\beta$ and $n$ will continue to match the respective reference values, even though those parameters are changing with time.

For swept wing icing scaling, the observations from recent work (Refs. 3 to 6) on ice accretion formations on swept wings have suggested that although there are distinct morphological differences in resulting ice accretion formations on unswept and swept wings, the fundamental physics of ice accretion appears to be the same. Thus all the similarity parameters recommended for unswept wing icing scaling should apply. However, some modifications to the local collection efficiency and the convective heat transfer coefficient in the freezing fraction expression at the stagnation line due to model sweep angle must be considered.

An effort was made in this study to develop an analytical expression for $\beta_{0}$ calculations on swept wings of NACA 0012 airfoil profile. Experimental evaluations of $\beta_{0}$ were also needed for the validation of such correlation. A new test method based on the icing-blade technique was developed for measuring the $\beta_{0}$ on a swept NACA 0012 wing section over a wide range of sweep angles as well as flow and icing cloud conditions.

\section{Nomenclature}

$A_{c} \quad$ Accumulation parameter (Eq. (6)), dimensionless

$b \quad$ Relative heat factor (Eq. (11)), dimensionless

$c \quad$ Airfoil chord, $\mathrm{cm}$

$c_{p} \quad$ Specific heat of air, cal/g K

$c_{p, w s} \quad$ Specific heat of water at the surface temperature, cal $/ \mathrm{g} \mathrm{K}$

$d$ Cylinder radius or twice the leading-edge radius of airfoil, $\mathrm{cm}$

$h_{c} \quad$ Convective heat-transfer coefficient, $\mathrm{cal} / \mathrm{sm}^{2} \mathrm{~K}$

$h_{f} \quad$ Water film thickness, $\mathrm{cm}$

$h_{G} \quad$ Gas-phase mass-transfer coefficient, $\mathrm{g} / \mathrm{sm}^{2}$

$K \quad$ Inertia parameter (Eq. (2)), dimensionless

$K_{0} \quad$ Modified inertia parameter (Eq. (1)), dimensionless

$L W C$ Cloud liquid-water content, $\mathrm{g} / \mathrm{m}^{3}$

$M V D$ Water droplet median volume diameter, $\mu \mathrm{m}$

$n \quad$ Local freezing fraction, dimensionless

$n_{0} \quad$ Stagnation freezing fraction (Eq. (8)), dimensionless

$p \quad$ Pressure, $\mathrm{Nt} / \mathrm{m}^{2}$

$p_{w} \quad$ Vapor pressure of water in atmosphere, $\mathrm{Nt} / \mathrm{m}^{2}$

$p_{w w}$ Vapor pressure of water at the icing surface, $\mathrm{Nt} / \mathrm{m}^{2}$

$r \quad$ Recovery factor, dimensionless

$\operatorname{Re}_{\delta} \quad$ Reynolds number of water drop (Eq. (3)), dimensionless

$s \quad$ Distance along airfoil surface measured from stagnation line, $\mathrm{cm}$

$t_{f} \quad$ Freezing temperature, ${ }^{\circ} \mathrm{C}$

$t_{s} \quad$ Surface temperature, ${ }^{\circ} \mathrm{C}$

$t \quad$ Air temperature, ${ }^{\circ} \mathrm{C}$

$T \quad$ Absolute air temperature, $\mathrm{K}$

$V \quad$ Air velocity, kt

$\mathrm{We}_{L} \quad$ Weber number based on model size and water properties (Eq. (13)), dimensionless

$\beta_{0} \quad$ Collection efficiency at stagnation line (Eq. (5)), dimensionless

$\phi \quad$ Droplet energy transfer parameter (Eq.(9)), ${ }^{\circ} \mathrm{C}$

$\lambda$ Droplet range, $m$

$\lambda_{\text {Stokes }}$ Droplet range if Stokes Law applies, $m$

$\Lambda \quad$ Sweep angle, degrees

$\Lambda_{f} \quad$ Latent heat of freezing, cal $/ \mathrm{g}$ 
$\Lambda_{v}$ Latent heat of condensation, cal $/ \mathrm{g}$

$\mu$ Air viscosity, $\mathrm{g} / \mathrm{m} \mathrm{s}$

$\theta$ Air energy transfer parameter (Eq. (10)), ${ }^{\circ} \mathrm{C}$

$\rho$ Air density, $g / \mathrm{m}^{3}$

$\rho_{i}$ Ice density, $\mathrm{g} / \mathrm{m}^{3}$

$\rho_{w}$ Liquid water density, $\mathrm{g} / \mathrm{m}^{3}$

$\sigma$ Surface tension of water over air, dyne $/ \mathrm{cm}$

$\tau$ Accretion time, min

\section{Subscripts}

$R$ reference

$S$ scale

$f$ water film

st static

tot total

\section{Modifications to Similarity Parameters for Swept Wing Icing Scaling}

The similarity parameters used in this study were based on the work originally done by Ruff (Ref. 7). The scaling method involved matching scale and reference values of the key similarity parameters, $\beta_{0}, A_{c}$, $n_{0}$, and $\mathrm{We}_{L}$. The equations for the similarity parameters will be presented here without much discussion. Therefore, readers who are interested in the physical descriptions and detailed derivations of these parameters are referred to References 1 and 2 and the references given therein.

To maintain the droplet trajectory similitude, Langmuir and Blodgett (Ref. 8) introduced the modified inertia parameter, $K_{0}$, defined as

$$
K_{0}=\frac{1}{8}+\frac{\lambda}{\lambda_{\text {Stokes }}}\left(K-\frac{1}{8}\right)
$$

for $K>0.125$, to describe the inertia of droplets in an air stream flowing around a cylinder of radius $d$ positioned normal to the flow. In Equation (1), $K$ is the inertia parameter,

$$
K=\frac{\rho_{w} M V D^{2} V}{18 d \mu} .
$$

Departing slightly from Langmuir and Blodgett in this study, $d$ represents twice the leading-edge radius of curvature for airfoils. For the NACA 0012 airfoil model, a leading-edge radius of $0.0158 c$ was used (see Abbott and von Doenhoff (Ref. 9)), where $c$ is the airfoil chord. In Equation (2), $\lambda / \lambda_{\text {Stokes }}$ is the droplet range parameter, defined as the ratio of actual droplet range to that if Stokes drag law for solidspheres applied. It is a function only of the droplet Reynolds number, $\operatorname{Re}_{\delta}$.

$$
\mathrm{Re}_{\delta}=\frac{V M V D \rho}{\mu}
$$

This study used a curve fit to Langmuir and Blodgett's tabulation of the range parameter as given in the following expression: 


$$
\frac{\lambda}{\lambda \text { Stokes }}=\frac{1}{\left(0.8388+0.001483 \operatorname{Re}_{\delta}+0.1847 \sqrt{\mathrm{Re}_{\delta}}\right)}
$$

Of more practical interest than $K_{0}$ is the collection efficiency at the stagnation point, $\beta_{0}$, which was shown by Langmuir and Blodgett to be a function only of $K_{0}$,

$$
\beta_{0}=\frac{1.40\left(K_{0}-\frac{1}{8}\right)^{.84}}{1+1.40\left(K_{0}-\frac{1}{8}\right)^{.84}}
$$

Thus the droplet trajectory similarity is satisfied if $K_{0, S}=K_{0, R}$ (so does $\beta_{0, S}=\beta_{0, R}$ ), and the scale drop size, i.e., scale $M V D$, is determined. For a NACA 0012 wing section at a given sweep angle $\Lambda$, it is suggested that, based on the observations made by Reshotko and Beckwith (Ref. 10) in their classical study of compressible laminar boundary layer over a swept infinite cylinder, the collection efficiency along the stagnation line, $\beta_{0, \Lambda}$, could be written in the following functional form

$$
\frac{\beta_{0, \Lambda}}{\beta_{0, \Lambda=0}}=(\cos \Lambda)^{m}
$$

where $\beta_{0, \Lambda=0}$ is calculated from Equation (5) and the exponent $m$ will be calibrated with the experimental data obtained in this study.

To ensure water-catch similarity, the accumulation parameter is introduced:

$$
A_{c}=\frac{L W C V \tau}{d \rho_{i}}
$$

If all the water impinging on the leading edge freezes at that location and the leading-edge collection efficiency is 100 percent, $A_{c}$ directly becomes a measure of the normalized thickness of ice that will accrete. The scale accretion time can be found from $A_{c, S}=A_{c, R}$. However if it is not possible to find scaled conditions that permit a match of $K_{0}$ (and therefore $\beta_{0}$ ) and $A_{c}$ separately, it is recommended that the product of $\beta_{0} A_{c}$ be matched provided the two collection efficiencies, $\beta_{0, S}$ and $\beta_{0, R}$, be within 10 percent, see Reference (1) for details.

When super-cooled water drops strike an aircraft surface, they may not freeze immediately on impact. The freezing fraction is the ratio of the amount of water that freezes in a specified region on the surface to the total amount of liquid water that reaches that region. Thus, local ice thickness depends on both $\beta_{0} A_{c}$ and freezing fraction. Because each local ice thickness around the model defines the overall shape of the ice, the freezing fraction obviously has a major influence on ice shape.

The rate at which the water freezes on a surface depends on the magnitude of local heat transfer imbalance. For glaze ice, it is known that the fraction of water that freezes is less than unity, and the motion of unfrozen surface water can have an effect on the resulting ice shape. Therefore, it is important to maintain surface energy and surface-water dynamics similarities for glaze ice accretions. The freezing fraction is formally defined as the ratio of the amount of water that freezes at a given surface location to the total amount of water that impinges at that location. From Messinger's (Ref. 11) steady-state surface energy balance analysis, the stagnation point freezing fraction can be written as 


$$
n_{0}=\frac{c_{p, w s}}{\Lambda_{f}}\left(\phi+\frac{\theta}{b}\right)
$$

The key terms in this formulation include $\phi$ and $\theta$, which have dimensions of temperature and relate to the water drop energy transfer and air energy transfer, and $b$, the relative heat factor, which was first introduced by Tribus, et al. (Ref. 12)

$$
\begin{gathered}
\varphi=t_{f}-t_{s t}-\frac{V^{2}}{2 c_{p, w s}} \\
\theta=\left(t_{s}-t_{s t}-r \frac{V^{2}}{2 c_{p}}\right)+\frac{h_{G}}{h_{c}}\left(\frac{\frac{p_{w w}}{T_{s t}}-\frac{p_{t o t}}{T_{t o t}} \frac{p_{w}}{p_{s t}}}{\left.\frac{1}{.622} \frac{p_{t o t}}{T_{t o t}}-\frac{p_{w w}}{T_{s t}}\right) \Lambda_{v}}\right. \\
b=\frac{L W C V \beta_{0} c_{p, w s}}{h_{c}}
\end{gathered}
$$

Equation (10) from Ruff (Ref. 7) has included compressibility effects. Various incompressible forms of $\theta$ have also been used by Charpin and Fasso (Ref. 13) and others; however, the differences are not significant mainly due to the fact that, for most icing conditions, the Mach number is relatively low. Since only limited combinations of $M V D$ s and $L W C$ s in the SLD regime are currently available in the IRT, the stagnation point freezing fraction is matched to find the scale static temperature instead of the scale $L W C$ value.

As for the effect of sweep angle on the convective heat transfer along the stagnation line of a NACA 0012 wing section, it was shown in Reference (10) that for incompressible flows the ratio of swept to normal convective heat transfer coefficient became

$$
\frac{h_{c, \Lambda}}{h_{c}}=(\cos \Lambda)^{\frac{1}{2}}
$$

As stated in the preceding paragraph Equation (12) is used mainly due to the fact that for most icing conditions, the Mach number is relatively low. Some experimental evaluations of this analytical expression for calculating the stagnation freezing fraction on a swept wing are needed. However, this is not the scope of the present study.

In 1988 Bilanin (Ref. 14) presented a Buckingham- $\pi$ analysis in which he concluded that surfacewater phenomena had to be included in icing scaling methods. Olsen and Walker (Ref. 15) and Hansman, et al. (Refs. 16 to 18) studied surface effects and surface water during ice accretion, presenting additional evidence that these were important phenomena to consider in ice accretion. From the close-up photographs of these research studies, it was observed that for glaze ice accretion unfrozen water on the ice surface tended to coalesce to form beads. These beads sometimes were swept downstream and sometimes froze in place. Bilanin (Refs. 14 and 19) also argued that drop splashing on impact might affect the shape of the ice accreted.

Hansman and Turnock (Ref. 16) found that when a surfactant was added to the icing spray water, the ice shape appearance and shape changed significantly, with the glaze horns moving toward the leading edge. Clearly, then, surface tension, and by implication, surface phenomena, have a significant role in the physics of ice accretion. 
In 2003 Anderson and Tsao (Ref. 20) had provided experimental evidence from past studies to show that a similarity parameter dependent on the ratio $V^{x} c^{y} / \sigma^{z}$ must be included in scaling methodology to account for surface-water dynamics effect in glaze ice accretions, although the powers $x, y$, and $z$ are not yet determined. The length may not be chord itself but rather some physical characteristic $L$ related to chord; for example, the water-film thickness. Likewise, the velocity could also be of the water-film that is related to $V$. Thus a Weber number based on $L$ and $V$

$$
\mathrm{We}_{L}=\frac{V^{2} L \rho_{w}}{\sigma}
$$

has been suggested as a potential additional similarity parameter to supplement Ruff's basic scaling method. Studies by Bartlett (Refs. 21 and 22) and Oleskiw, et al. (Ref. 23) found no measurable effect of pressure on ice shape. These observations suggest that water density is a better choice than air density for Equation (13). In this study the $\mathrm{We}_{L}$ is based on the twice the nose radius of the airfoil:

$$
\mathrm{We}_{L}=\frac{V^{2} d \rho_{w}}{\sigma}
$$

with the understanding that $L \propto d$ The scale velocity found from matching $\mathrm{We}_{L, S}=\mathrm{We}_{L, R}$ is

$$
V_{S}=V_{R}\left(\frac{d_{R}}{d_{S}}\right)^{1 / 2}
$$

\section{Test Description}

\section{Facility, Model, and Procedures}

The icing tests were performed in the NASA Glenn Icing Research Tunnel (IRT). The IRT is a closed-loop, refrigerated, sea level tunnel with a 1.8 by $2.7 \mathrm{~m}$ rectangular test section. The icing cloud is generated by operating 10 spray bars, a configuration in use since 1998 .

The IRT cloud calibrations for both Appendix C and SLD conditions used for these tests were performed in the summer of 2006. The $L W C$ and $M V D$ measurements were made using methods reported previously (Ref. 24). However, the $L W C$ measurements from the Mod-1 nozzles have been updated in August-September 2008. Thus, the definition of $L W C$ for a particular cloud may differ from values previously reported, particularly for the low $L W C$ value range of Appendix $\mathrm{C}$ regime. For example, for given spray-bar pressures, the latest calibration gives $L W C$ s of 85 to 100 percent of those obtained in a 2006 calibration. The $L W C$ s reported in this paper are based on an analysis of the $L W C$ calibration data completed in 2006 for Standard nozzles and in 2008 for Mod-1 nozzles. In addition, because only a limited range of $M V D-L W C$ combinations for speeds of 51,77, 103, and $129 \mathrm{~m} / \mathrm{s}(100,150,200$, and $250 \mathrm{kt}$ ) have been calibrated to date in the SLD regime, additional $L W C$ measurements for selected SLD conditions were made in the IRT on September 22, 2008, with an icing blade. Therefore SLD tests are constrained to these particular conditions.

The model used in this study was a NACA 0012 Swept Wing Tip. The airfoil has a $38.1 \mathrm{~cm}$ (15 in.) chord and a $88.9 \mathrm{~cm}(35 \mathrm{in}$.) span. It is mounted on a stand in the tunnel that allows pivoting of the airfoil to sweep angles from $0^{\circ}$ to $60^{\circ}$ by $5^{\circ}$ increments. Multiple chord-wise gridlines were marked around the airfoil leading edge at the tunnel vertical center and $\pm 2.54 \mathrm{~cm} \times(1,2,3,4)$ from the center to help locate ice-tracing templates and to serve as a distance scale in some close-up photographs. Because of the quickstart capability of the IRT spray system, no shielding of the model was required during the initiation of the spray. 
Two different configurations of the model in the test section were used in the experiment. One of the configurations was required to further elevate the gridline portion of the model close to the vertical center of the tunnel when sweep angle is larger than $30^{\circ}$. This will ensure the measurements of leading edge ice thickness from the swept wing model are always made at the vertical center of the tunnel and $\pm 2.5 \mathrm{~cm}$ from the center.

The first configuration (Configuration A, Fig. 1) was the standard position of the model in the test section. In this position the model is sitting on a table bolted to the floor of the tunnel and the middle gridline on the airfoil is about $91 \mathrm{~cm}$ from the floor of the tunnel. In the second configuration (Configuration B, Fig. 2) the model was raised additional $7.6 \mathrm{~cm}$ (i.e., 3 in.) from the floor to allows new gridlines be drawn on the model about $91 \mathrm{~cm}$ from the floor of the tunnel when the model was set at $45^{\circ}$ sweep angle.

In preparing for a test, the temperature and airspeed in the test section and the air and water pressures on the spray manifolds were set. When these conditions had stabilized, the spray nozzle valves were opened to initiate the spray. The spray was timed for the required duration, and then turned off. The fan was brought to a full stop and the researchers entered the test section to document the ice shape with hand tracings. Close-up photographs were also taken with a hand-held digital camera.

To record the ice shapes, a thin slice was first melted through the ice normal to the model surface. A cardboard template was then placed into this slit and an outline of the ice shape traced by pencil, giving a two-dimensional cross section of the ice. Tracings were taken at the vertical center of the tunnel (i.e., $91 \mathrm{~cm}$ from the floor) and at $\pm 2.5 \mathrm{~cm}$ from the center. The ice shapes so recorded were digitized using an automated line-following feature in the image-analysis software, SigmaScan Pro (Ref. 25).

In 1988 Bilanin (Ref. 14) noted that the leading-edge ice thickness, $\Delta$, is related to the stagnation point freezing fraction, $n_{0}$, accumulation parameter, $A_{c}$, stagnation point collection efficiency, $\beta_{0}$, and cylinder diameter, $d$ as follows:

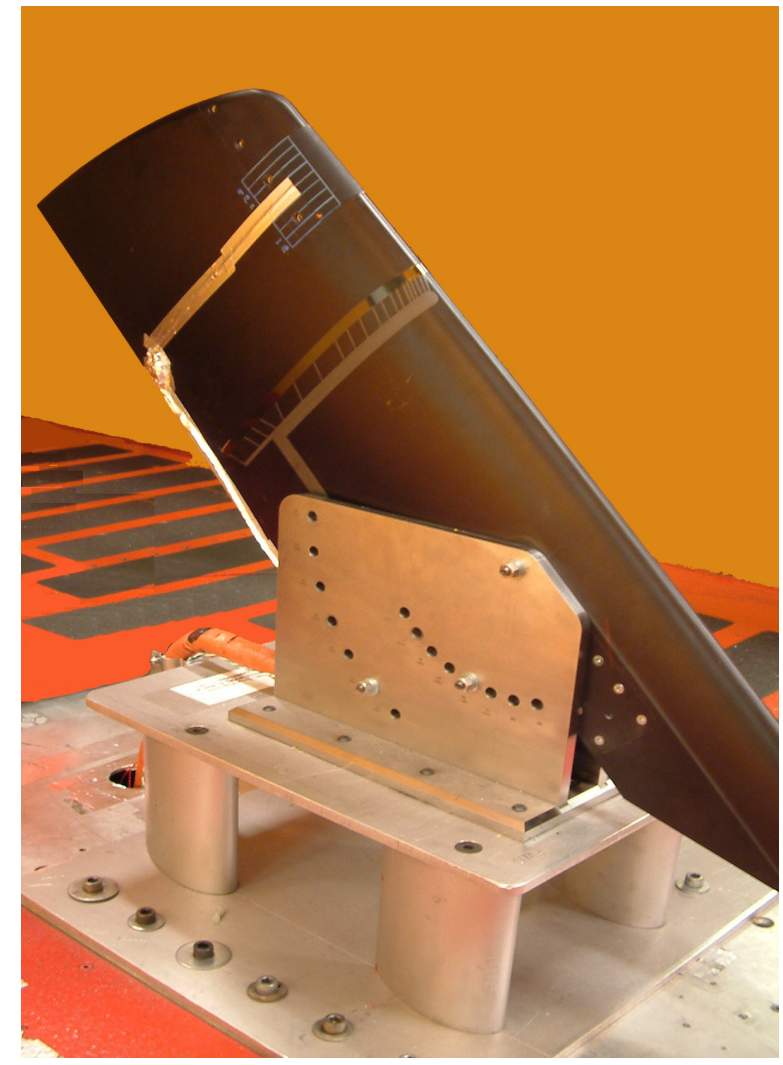

Figure 1.-Configuration A for sweep angle $\leqq 30^{\circ}$.

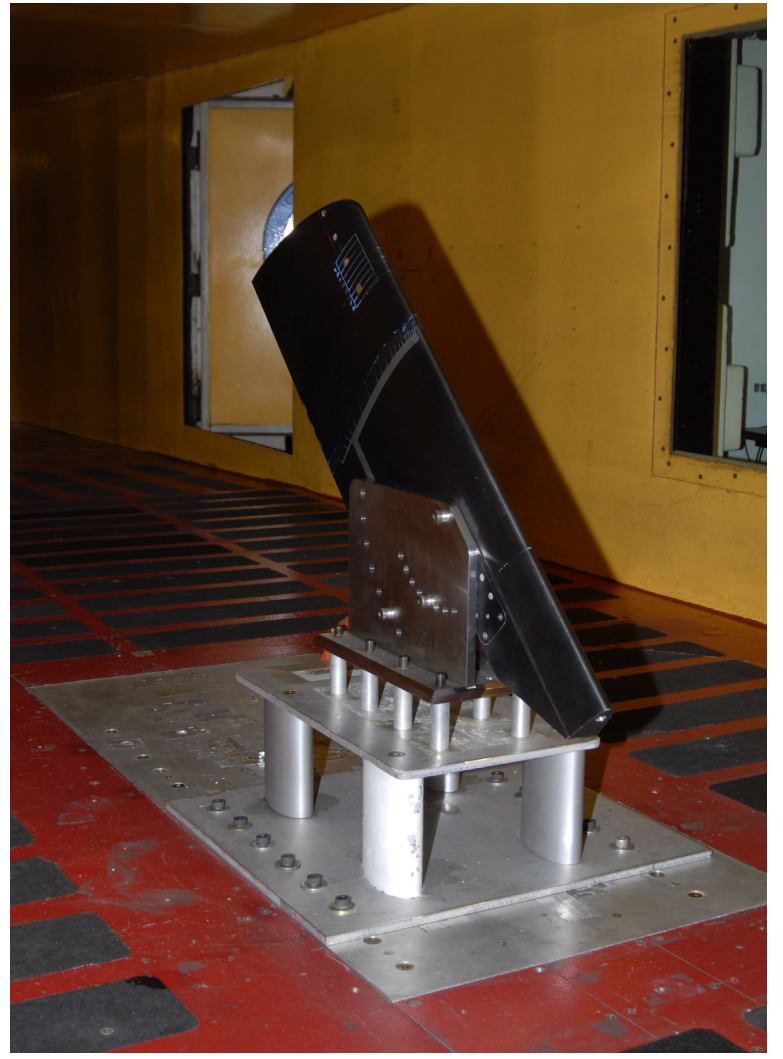

Figure 2.-Configuration B for sweep angle $>30^{\circ}$. 


$$
\frac{\Delta}{d}=n_{0} A_{c} \beta_{0}
$$

In 2003 Anderson and Tsao (Ref. 26) have measured the leading-edge thickness of a number of ice shapes recorded on NACA 0012 airfoil models for a variety of test conditions in the IRT and then used Equation (16) to experimentally determine the stagnation point freezing fraction provided $\beta_{0}$ and $A_{c}$ were calculated from Equations (5) and (7), respectively, using the conditions at which the ice was accreted.

In this study, a new test method was developed to evaluate the stagnation point collection efficiency $\beta_{0}$ of the NACA 0012 swept wing tip. It requires that, for a spray of known $M V D$ at a given airspeed $V$, a rime condition (i.e., $n_{0}=1$ ) be run over the swept wing tip at a selected sweep angle for some period of spray time $\tau$. Mathmatically, the $\beta_{0}$ is related to the leading-edge ice thickness $\Delta$, the spray $L W C$ and the spray time $\tau$ from Equation (16) as follows:

$$
\left(\beta_{0, \Lambda}\right)_{\exp }=\frac{\Delta}{d A_{c}}=\frac{\rho_{i} \Delta}{L W C V \tau}
$$

Two quick entries in the IRT were made in February 2007 and May 2008 to determine the optimal settings for $L W C$, spray time $\tau$, and total air temperature $t_{t o t}$ to produce a good amount of rime ice thickness at the leading edge of the swept wing tip for better measurement uncertainty control. In the September 2008 test, the actual values of $L W C, \tau$ and $t_{\text {tot }}$ were chosen by satisfying the following two constraints: (1) $n_{0}=1$ provided $t_{t o t}=0{ }^{\circ} \mathrm{F}$ or lower if needed, and (2) $A_{c}=1$. For most of the SLD conditions tested in this study, a moderate $L W C$ value about $0.5 \mathrm{~g} / \mathrm{m}^{3}$ was found to satisfy both constraints and the spray could produce a reasonable rime ice thickness in the order of 8 to $11 \mathrm{~mm}$ at the leading edge for 3 to $7 \mathrm{~min}$ of spray time. The only exception is for the $M V D$ of $102 \mu \mathrm{m}$ at $150 \mathrm{kt}$ case, the spray has a $L W C$ value of $0.79 \mathrm{~g} / \mathrm{m}^{3}$, the $t_{\text {tot }}$ is reduced to $-5^{\circ} \mathrm{F}$ to insure rime.

To calibrate the proposed correlation of Equation (6), six SLD conditions were used in the September 2008 test, see Table 1 for the spray-bar settings defined by nozzle atomizing air pressure, $p_{\text {air, }}$ and airwater pressure difference, $\Delta p_{w}$, to experimentally evaluate the collection efficiency at the stagnation line of the NACA 0012 swept wing tip over a range of modified inertia parameter $K_{0}$ and sweep angle.

TABLE 1.-TEST CONDITIONS

[All tests with 38.1-cm-chord NACA 0012 swept wing tip.]

\begin{tabular}{|c|r|r|c|r|c|c|c|c|r|r|}
\hline$\Lambda$, & $\begin{array}{c}t_{s t}, \\
0\end{array}$ & $\begin{array}{c}t_{t o t}, \\
{ }^{\circ} \mathrm{F}\end{array}$ & $\begin{array}{c}V, \\
\mathrm{kt}\end{array}$ & $\begin{array}{c}M V D, \\
\mu \mathrm{m}\end{array}$ & $\begin{array}{c}L W C \mathrm{~m}^{3} \\
\mathrm{~g} /\end{array}$ & $\begin{array}{c}\tau, \\
\mathrm{min}\end{array}$ & $\begin{array}{c}p_{\text {air }} \\
\mathrm{psig}\end{array}$ & $\begin{array}{c}\Delta p_{w}, \\
\mathrm{psid}\end{array}$ & \multicolumn{1}{|c|}{$K_{0}$} & $A_{c}$ \\
\hline 15 & -2.4 & 0 & 100 & 36 & 0.56 & 6.39 & 6 & 20 & 5.75 & 1 \\
15 & -5.3 & 0 & 150 & 42 & 0.43 & 5.54 & 5 & 20 & 9.28 & 1 \\
15 & -10.3 & -5 & 150 & 102 & 0.79 & 3.02 & 6 & 50 & 35.47 & 1 \\
15 & -9.5 & 0 & 200 & 36 & 0.30 & 5.96 & 6 & 20 & 8.68 & 1 \\
15 & -9.5 & 0 & 200 & 82 & 0.45 & 3.97 & 5 & 35 & 29.98 & 1 \\
15 & -14.8 & 0 & 250 & 97 & 0.23 & 6.22 & 3 & 20 & 43.44 & 1 \\
\hline 30 & -2.4 & 0 & 100 & 36 & 0.56 & 6.39 & 6 & 20 & 5.75 & 1 \\
30 & -5.3 & 0 & 150 & 42 & 0.43 & 5.54 & 5 & 20 & 9.28 & 1 \\
30 & -10.3 & -5 & 150 & 102 & 0.79 & 3.02 & 6 & 50 & 35.47 & 1 \\
30 & -9.5 & 0 & 200 & 36 & 0.30 & 5.96 & 6 & 20 & 8.68 & 1 \\
30 & -9.5 & 0 & 200 & 82 & 0.45 & 3.97 & 5 & 35 & 29.98 & 1 \\
30 & -14.8 & 0 & 250 & 97 & 0.23 & 6.22 & 3 & 20 & 43.44 & 1 \\
\hline 45 & -2.4 & 0 & 100 & 36 & 0.56 & 6.39 & 6 & 20 & 5.75 & 1 \\
45 & -5.3 & 0 & 150 & 42 & 0.43 & 5.54 & 5 & 20 & 9.28 & 1 \\
45 & -10.3 & -5 & 150 & 102 & 0.79 & 3.02 & 6 & 50 & 35.47 & 1 \\
45 & -9.5 & 0 & 200 & 36 & 0.30 & 5.96 & 6 & 20 & 8.68 & 1 \\
45 & -9.5 & 0 & 200 & 82 & 0.45 & 3.97 & 5 & 35 & 29.98 & 1 \\
45 & -14.8 & 0 & 250 & 97 & 0.23 & 6.22 & 3 & 20 & 43.44 & 1 \\
\hline
\end{tabular}


The leading-edge ice thickness for each rime ice shape was measured using a chilled micrometer. Three measurements were taken at the vertical center of the tunnel and at $\pm 2.5 \mathrm{~cm}$ from the center. The medium value of ice thickness measurements was used in Equation (17) to calculate the $\left(\beta_{0, \Lambda}\right)_{\text {exp }}$. The results presented in this study are from IRT test entry in September 2008.

\section{Uncertainty Analysis}

Estimates of the uncertainty in the reported average conditions were made by considering inherent errors of instruments, temporal fluctuation and spatial variation of the instrument readings in the test section, and uncertainty in tunnel calibration of $M V D$ and $L W C$. Recorded air temperature was believed to be accurate to $\pm 0.5^{\circ} \mathrm{C}$, and the uncertainty in air velocity were estimated to be $\pm 1 \mathrm{~m} / \mathrm{s}$. For Appendix $\mathrm{C}$ conditions the net uncertainty in $M V D$ was estimated at \pm 12 percent. For SLD conditions it may have been as much as \pm 20 percent. These uncertainties are not referenced to an absolute value of $M V D$, which is unknown. Repeatability and scatter in the $L W C$ calibration data suggests the uncertainty is about \pm 12 percent for both Appendix C and SLD conditions. The test-parameter uncertainties were used to estimate the following uncertainties in the similarity parameters for the SLD tests: 12 percent in $A_{c}$, 10 percent in $n_{0}$, and 3 percent in $\mathrm{We}_{L}$.

As for the uncertainty of calculating $\left(\beta_{0, \Lambda}\right)_{\exp }$ from Equation (17), a leading-order-term estimate was made and showed that it depends primarily on the uncertainties of $L W C$ and the leading-edge ice thickness $\Delta$ :

$$
\frac{d\left(\beta_{0, \Lambda}\right)_{\exp }}{\left(\beta_{0, \Lambda}\right)_{\exp }} \approx \sqrt{\left(\frac{d \Delta}{\Delta}\right)^{2}+\left(\frac{d L W C}{L W C}\right)^{2}}
$$

With an approximate uncertainty of \pm 5 percent in $\Delta$ measurement and \pm 12 percent in $L W C$ the uncertainty of $\left(\beta_{0, \Lambda}\right)_{\exp }$ is about \pm 13 percent. It is apparent that accurate $L W C$ measurements in the IRT are critical in obtaining accurate stagnation point collection efficiency results.

\section{Results}

The experimental measurement data of leading-edge rime ice thickness $\Delta$ and the calculated $\left(\beta_{0, \Lambda}\right)_{\exp }$ on NACA 0012 swept wing tip were presented in Table 2. From the measurement data, two important observations were immediately noticed:

1. For sweep angles up to $45^{\circ}$ and the modified inertia parameter $K_{0}$ with values ranging from 6 to 35 , the best correlation, based on the form proposed in Equation (6), for calculating $\beta_{0, \Lambda}$ of the NACA 0012 swept wing tip is

$$
\left(\beta_{0, \Lambda}\right)_{\text {theory }}=\beta_{0, \Lambda=0}(\cos \Lambda)
$$

For each test condition listed in Table 1, the predicted $\beta_{0, \Lambda}$ value from Equation (19) and the corresponding ratio of experimental to analytical value of $\beta_{0, \Lambda}$ were provided in Table 2 for numerical comparison. With the estimated \pm 13 percent uncertainty in determining $\left(\beta_{0, \Lambda}\right)_{\exp }$ as discussed in the previous section, the proposed correlation was considered to perform reasonably well over the range of test conditions. In addition, Figure 3 compares the experimental and theoretical trends of $\beta_{0, \Lambda} / \cos \Lambda$ varying with $K_{0}$, and again it shows that the correlation simulates well the experimental data. 
2. There was evidence which seemed to indicate that some ice erosion occurred for the rime ice shapes obtained at 250 knots in the IRT. Figure 4 showed an eroded rime ice tracing and in Figure 5, the corresponding close-up photo, the resulting ice shape looked very smooth and lacked the expected small-scale rime ice feathers. Furthermore, the stagnation point ice thickness measurements at higher speeds were usually much smaller than would have been expected without any ice erosion. Consequently, those 250 knot measurement data have been excluded from the current post-test analysis for determining the correlation and will be examined further.

TABLE 2.-MEASUREMENT RESULTS FOR $\left(\beta_{0, \Lambda}\right)_{\exp }$

[All tests with 38.1-cm-chord NACA 0012 swept wing tip.]

\begin{tabular}{|c|r|c|r|r|r|r|r|r|r|r|}
\hline $\begin{array}{c}\Lambda, \\
0\end{array}$ & $\begin{array}{r}t_{\text {tot }}, \\
{ }^{\circ} \mathrm{F}\end{array}$ & $\begin{array}{c}V, \\
\mathrm{kt}\end{array}$ & $\begin{array}{c}M V D, \\
\mu \mathrm{m}\end{array}$ & $\begin{array}{c}L W C, \\
\mathrm{~g} / \mathrm{m}^{3}\end{array}$ & $\begin{array}{c}\tau, \\
\min \end{array}$ & $K_{0}$ & $\begin{array}{c}\Delta, \\
\mathrm{mm}\end{array}$ & $\left(\beta_{0, \Lambda}\right)_{\exp }$ & $\begin{array}{c}\left(\beta_{0, \Lambda}\right)_{\text {theory }} \\
\left(\beta_{0, \Lambda}\right)_{\mathrm{e}} /\left(\beta_{0, \Lambda}\right)_{\mathrm{t}}, \\
\text { percent }\end{array}$ \\
\hline 15 & 0 & 100 & 36 & 0.56 & 6.39 & 5.75 & 9.11 & 0.757 & 0.827 & 91.5 \\
15 & 0 & 150 & 42 & 0.43 & 5.54 & 9.28 & 10.05 & 0.835 & 0.869 & 96.1 \\
15 & -5 & 150 & 102 & 0.79 & 3.02 & 35.47 & 10.33 & 0.858 & 0.933 & 92.0 \\
15 & 0 & 200 & 36 & 0.30 & 5.96 & 8.68 & 9.26 & 0.770 & 0.864 & 89.1 \\
15 & 0 & 200 & 82 & 0.45 & 3.97 & 29.98 & 11.26 & 0.937 & 0.928 & 100.9 \\
15 & 0 & 250 & 97 & 0.23 & 6.22 & 43.44 & 7.85 & 0.653 & 0.938 & 69.6 \\
\hline 30 & 0 & 100 & 36 & 0.56 & 6.39 & 5.75 & 9.77 & 0.812 & 0.742 & 109.4 \\
30 & 0 & 150 & 42 & 0.43 & 5.54 & 9.28 & 8.85 & 0.736 & 0.779 & 94.4 \\
30 & -5 & 150 & 102 & 0.79 & 3.02 & 35.47 & 9.02 & 0.750 & 0.836 & 89.7 \\
30 & 0 & 200 & 36 & 0.30 & 5.96 & 8.68 & 8.98 & 0.746 & 0.775 & 96.3 \\
30 & 0 & 200 & 82 & 0.45 & 3.97 & 29.98 & 8.92 & 0.741 & 0.832 & 89.1 \\
30 & 0 & 250 & 97 & 0.23 & 6.22 & 43.44 & 8.37 & 0.696 & 0.841 & 82.8 \\
\hline 45 & 0 & 100 & 36 & 0.56 & 6.39 & 5.75 & 7.33 & 0.609 & 0.606 & 100.6 \\
45 & 0 & 150 & 42 & 0.43 & 5.54 & 9.28 & 7.35 & 0.611 & 0.636 & 96.1 \\
45 & -5 & 150 & 102 & 0.79 & 3.02 & 35.47 & 7.33 & 0.609 & 0.683 & 89.2 \\
45 & 0 & 200 & 36 & 0.30 & 5.96 & 8.68 & 7.87 & 0.655 & 0.633 & 103.5 \\
45 & 0 & 200 & 82 & 0.45 & 3.97 & 29.98 & 7.20 & 0.599 & 0.679 & 88.1 \\
45 & 0 & 250 & 97 & 0.23 & 6.22 & 43.44 & 5.47 & 0.455 & 0.686 & $\mathrm{a}$ \\
\end{tabular}

${ }^{\mathrm{a}}$ Ice shape erosion in the IRT.

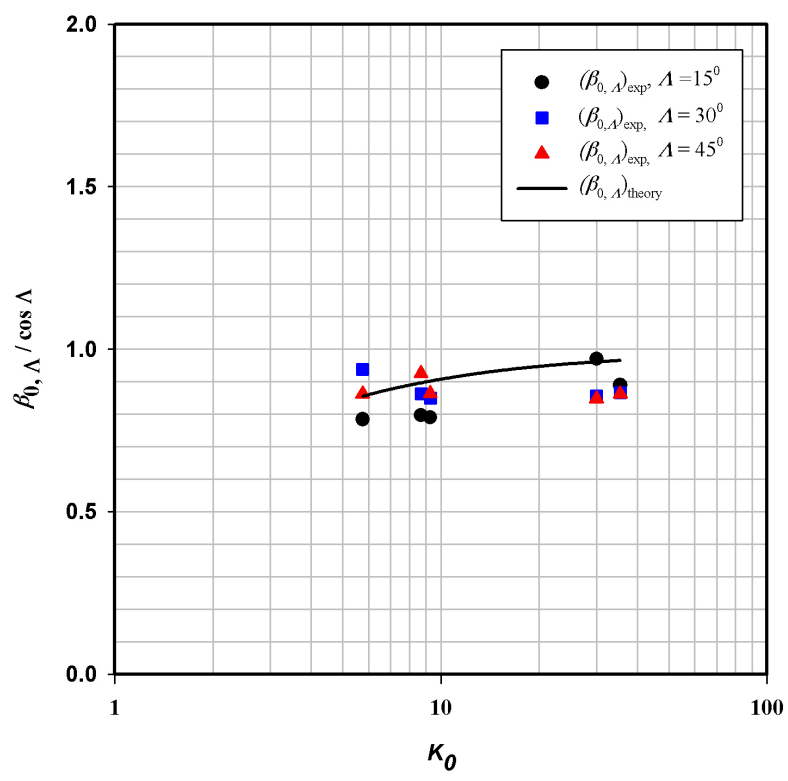

Figure 3.-Experimental and analytical variation of $\left(\beta_{0, \Lambda} / \cos \Lambda\right)$ versus $K_{0}$ compared. $\left(\beta_{0, \Lambda}\right)_{\text {theory }}$ calculated using Equation (19). 


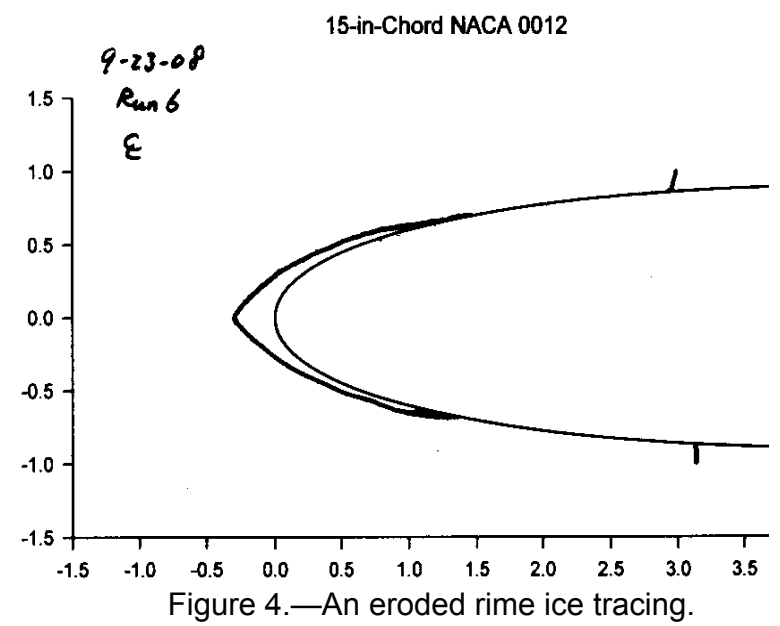

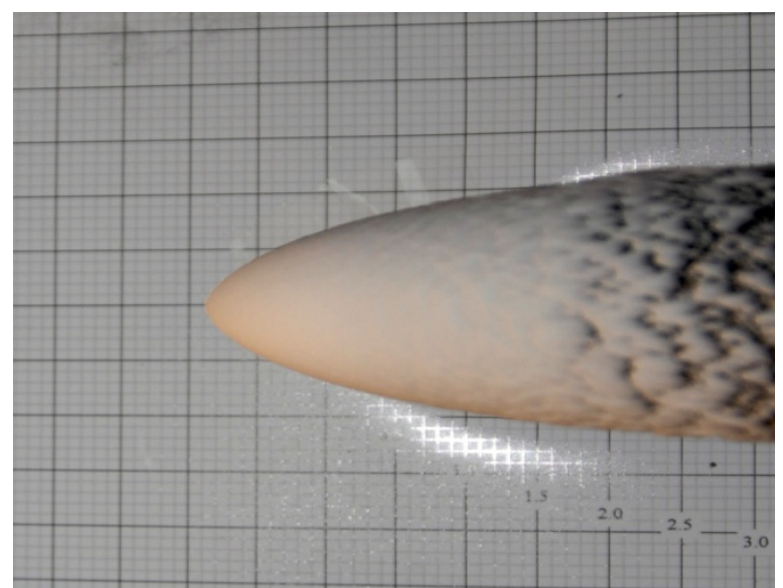

Figure 5.-The close-up image for September 23, 2008, run 6.

\section{Conclusion}

Icing tests were performed in the NASA Glenn Icing Research Tunnel to develop a test method for measuring the stagnation point collection efficiency of the NACA 0012 swept wing tip. The data obtained were used to calibrate a proposed correlation for such collection efficiency calculation as a function of the modified inertia parameter and the sweep angle.

The preliminary results showed the effectiveness of the test method developed in the IRT could be somewhat limited due to the ice erosion problem encountered. It also showed that accurate $L W C$ measurements in the IRT are essential in obtaining stagnation point collection efficiency results. The correlation of $\beta_{0} \cos \Lambda$ was found to approximate the experimental $\beta_{0, \Lambda}$ reasonably well for sweep angles up to $45^{\circ}$ and the modified inertia parameter $K_{0}$ in the value range of 6 to 35 . Further evaluation of the correlation over a wider flow/icing cloud conditions as well as different model sizes is recommended to assess its applicability for swept-wing icing scaling analysis.

\section{References}

1. Anderson, D.N., "Manual of Scaling Methods," NASA/CR-2004-212875, March 2004.

2. Anderson, D.N and Tsao, J.C., "Ice Shape Scaling for Aircraft in SLD Conditions," NASA/CR2008-215302 and DOT/FAA/AR-07/55, September 2008.

3. Vargas, M., "Current Experimental Basis for Modeling Ice Accretions on Swept Wings," AIAA-2005-5188, June 2005.

4. Vargas, M. and Tsao, J.C., "Observations on the Growth of Roughness Elements into Icing Feathers," AIAA-2007-0900, January 2007.

5. Vargas, M., Tsao, J.C. and Rothmayer, A., "Review of Role of Icing Feathers in Ice Accretion Formation," SAE-2007-01-3294, September 2007.

6. Vargas, M. and Tsao, J.C., "Time-Sequence Observations of the Formation of Ice Accretions on Swept Wings," AIAA-2008-0470, January 2008.

7. Ruff, G.A., "Analysis and Verification of the Icing Scaling Equations," AEDC-TR-85-30, vol 1 (rev), March 1986.

8. Langmuir, Irving and Blodgett, Katharine B. "A Mathematical Investigation of Water Droplet Trajectories,” Army Air Forces Technical Report No. 5418, February 1946.

9. Abbott, Ira H. and von Doenhoff, Albert E., Theory of Wing Sections, Dover, New York, 1959, pp. 114 and 321.

10. Reshotko, Eli and Beckwith, Ivan, "Compressible Laminar Boundary Layer Over a Yawed Infinite Cylinder With Heat Transfer and Arbitrary Prandtl Number,” NACA Rep. 1379, 1957. 
11. Messinger, B.L., "Equilibrium Temperature of an Unheated Icing Surface as a Function of Airspeed," J. Aeron. Sci., vol. 20 no. 1, January 1953, pp. 29-42.

12. Tribus, Myron, Young, G.B.W. and Boelter, L.M.K., "Analysis of Heat Transfer Over a Small Cylinder in Icing Conditions on Mount Washington," Trans. ASME, vol. 70, November 1948, pp. 971-976.

13. Charpin, Francois and Fasso, Guy, "Essais de givrage dans la grande soufflerie de Modane sur maquettes a echelle grandeur et echelle reduite," L'Aeronautique et l'Astronautique, no. 38, 1972, pp. 23-31. English translation published as "Icing Testing in the Large Modane Wind-Tunnel on Full-Scale and Reduced Scale Models," NASA TM-75373, March 1979.

14. Bilanin, A.J., "Proposed Modifications to the Ice Accretion/Icing Scaling Theory," AIAA-88-0203, January 1988.

15. Olsen, W. and Walker, E., "Experimental Evidence for Modifying the Current Physical Model for Ice Accretion on Aircraft Surfaces," NASA TM 87184, 1986.

16. Hansman, R. John, Jr. and Turnock, Stephen, R., "Investigation of Surface Water Behavior During Glaze Ice Accretion," J. Aircraft, vol. 26 no. 2, February 1989, pp. 140-147.

17. Hansman, R. John, Jr. and Turnock, Stephen R., "Investigation of Microphysical Factors Which Influence Surface Roughness During Glaze Ice Accretion," 4th International Workshop on Atmospheric Icing of Structures, Paris, September 1988.

18. Hansman, R.J., Breuer, K.S., Hazan, D., Reehorst, A. and Vargas, M., "Close-up Analysis of Aircraft Ice Accretion," AIAA-93-0029, January 1993.

19. Bilanin, Alan J. and Anderson, David N., "Ice Accretion With Varying Surface Tension," AIAA-950538 and NASA TM 106826, January 1995.

20. Anderson, David N. and Tsao, J.C., "Additional Results of Ice-Accretion Scaling at SLD Conditions," AIAA-2003-0390, January 2003 and NASA/CR-2005-213850, August 2005.

21. Bartlett, C. Scott, "An Analytical Study of Icing Similitude for Aircraft Engine Testing," DOT/FAA/CT-86/35 and AEDC-TR-86-26, October 1986.

22. Bartlett, C. Scott, "Icing Scaling Considerations for Aircraft Engine Testing," AIAA-88-0202, January 1988.

23. Oleskiw, Myron M., De Gregorio, Fabrizio and Esposito, Biagio, "The Effect of Altitude on Icing Tunnel Airfoil Icing Simulation," Proceedings of the FAA International Conference on Aircraft Inflight Icing, DOT/FAA/AR-96/81,II, August 1996, pp. 511-520.

24. Ide, Robert F. and Oldenburg, John R., "Icing Cloud Calibration of the NASA Glenn Icing Research Tunnel," AIAA-2001-0234, January 2001.

25. SigmaScan Pro, image-processing software, ver. 5.0, Systat Software, Inc., Point Richmond, CA.

26. Anderson, David N. and Tsao, J.C., "Evaluation and Validation of the Messinger Freezing Fraction," AIAA-2003-1218, January 2003. 


\begin{tabular}{|c|c|c|c|c|c|}
\hline \multicolumn{5}{|c|}{ REPORT DOCUMENTATION PAGE } & $\begin{array}{c}\text { Form Approved } \\
\text { OMB No. 0704-0188 }\end{array}$ \\
\hline \multicolumn{6}{|c|}{$\begin{array}{l}\text { The public reporting burden for this collection of information is estimated to average } 1 \text { hour per response, including the time for reviewing instructions, searching existing data sources, gathering and maintaining the } \\
\text { data needed, and completing and reviewing the collection of information. Send comments regarding this burden estimate or any other aspect of this collection of information, including suggestions for reducing this } \\
\text { burden, to Department of Defense, Washington Headquarters Services, Directorate for Information Operations and Reports (0704-0188, } 1215 \text { Jefferson Davis Highway, Suite } 1204 \text {, Arlington, VA } 22202-4302 \text {. } \\
\text { Respondents should be aware that notwithstanding any other provision of law, no person shall be subject to any penalty for failing to comply with a collection of information if it does not display a currently valid OMB } \\
\text { control number. } \\
\text { PLEASE DO NOT RETURN YOUR FORM TO THE ABOVE ADDRESS. }\end{array}$} \\
\hline \multicolumn{2}{|c|}{$\begin{array}{l}\text { 1. REPORT DATE (DD-MM-YYYY) } \\
01-03-2010\end{array}$} & \multicolumn{3}{|c|}{$\begin{array}{l}\text { 2. REPORT TYPE } \\
\text { Technical Memorandum }\end{array}$} & 3. DATES COVERED (From - To) \\
\hline \multirow{3}{*}{\multicolumn{5}{|c|}{$\begin{array}{l}\text { 4. TITLE AND SUBTITLE } \\
\text { Experimental Evaluation of Stagnation Point Collection Efficiency of the NACA } 0012 \text { Swe } \\
\text { Wing Tip }\end{array}$}} & 5a. CONTRACT NUMBER \\
\hline & & & & & 5b. GRANT NUMBER \\
\hline & & & & & 5c. PROGRAM ELEMENT NUMBER \\
\hline \multirow{3}{*}{\multicolumn{5}{|c|}{$\begin{array}{l}\text { 6. AUTHOR(S) } \\
\text { Tsao, Jen-Ching; Kreeger, Richard, E. }\end{array}$}} & 5d. PROJECT NUMBER \\
\hline & & & & & 5e. TASK NUMBER \\
\hline & & & & & $\begin{array}{l}\text { 5f. WORK UNIT NUMBER } \\
\text { WBS 457280.02.07.03.03.04 }\end{array}$ \\
\hline \multicolumn{5}{|c|}{$\begin{array}{l}\text { 7. PERFORMING ORGANIZATION NAME(S) AND ADDRESS(ES) } \\
\text { National Aeronautics and Space Administration } \\
\text { John H. Glenn Research Center at Lewis Field } \\
\text { Cleveland, Ohio 44135-3191 }\end{array}$} & $\begin{array}{l}\text { 8. PERFORMING ORGANIZATION } \\
\text { REPORT NUMBER } \\
\text { E-17152 }\end{array}$ \\
\hline \multirow{2}{*}{\multicolumn{5}{|c|}{$\begin{array}{l}\text { 9. SPONSORING/MONITORING AGENCY NAME(S) AND ADDRESS(ES) } \\
\text { National Aeronautics and Space Administration } \\
\text { Washington, DC 20546-0001 }\end{array}$}} & $\begin{array}{l}\text { 10. SPONSORING/MONITOR'S } \\
\text { ACRONYM(S) } \\
\text { NASA }\end{array}$ \\
\hline & & & & & $\begin{array}{l}\text { 11. SPONSORING/MONITORING } \\
\text { REPORT NUMBER } \\
\text { NASA/TM-2010-216102 }\end{array}$ \\
\hline \multicolumn{6}{|c|}{$\begin{array}{l}\text { 12. DISTRIBUTION/AVAILABILITY STATEMENT } \\
\text { Unclassified-Unlimited } \\
\text { Subject Category: } 03 \\
\text { Available electronically at http://gltrs.grc.nasa.gov } \\
\text { This publication is available from the NASA Center for AeroSpace Information, 443-757-5802 }\end{array}$} \\
\hline \multicolumn{6}{|c|}{ 13. SUPPLEMENTARY NOTES } \\
\hline \multirow{2}{*}{\multicolumn{6}{|c|}{$\begin{array}{l}\text { 14. ABSTRACT } \\
\text { This paper presents the experimental work of a number of icing tests conducted in the Icing Research Tunnel at NASA Glenn Research } \\
\text { Center to develop a test method for measuring the local collection efficiency of an impinging cloud at the leading edge of a NACA } 0012 \\
\text { swept wing and with the data obtained to further calibrate a proposed correlation for such impingement efficiency calculation as a function } \\
\text { of the modified inertia parameter and the sweep angle. The preliminary results showed that there could be some limitation of the test method } \\
\text { due to the ice erosion problem when encountered, and also found that, for conditions free of such problem, the stagnation point collection } \\
\text { efficiency measurement for sweep angles up to } 45^{\circ} \text { could be well approximated by the proposed correlation. Further evaluation of this } \\
\text { correlation is recommended in order to assess its applicability for swept-wing icing scaling analysis. } \\
\text { 15. SUBJECT TERMS } \\
\text { IRT; Experimental tests; Impinging cloud; Leading edge }\end{array}$}} \\
\hline & & & & & \\
\hline \multicolumn{3}{|c|}{ 16. SECURITY CLASSIFICATION OF: } & $\begin{array}{l}\text { 17. LIMITATION OF } \\
\text { ABSTRACT }\end{array}$ & $\begin{array}{l}\text { 18. NUMBER } \\
\text { OF }\end{array}$ & $\begin{array}{l}\text { 19a. NAME OF RESPONSIBLE PERSON } \\
\text { STI Help Desk (email:help@ } a \text { sti.nasa.gov) }\end{array}$ \\
\hline $\begin{array}{l}\text { a. REPORT } \\
\text { U }\end{array}$ & $\begin{array}{l}\text { b. ABSTRACT } \\
\text { U }\end{array}$ & $\begin{array}{l}\text { c. THIS } \\
\text { PAGE } \\
\text { U }\end{array}$ & UU & $\begin{array}{l}\text { PAGES } \\
18\end{array}$ & $\begin{array}{l}\text { 19b. TELEPHONE NUMBER (include area code) } \\
443-757-5802\end{array}$ \\
\hline
\end{tabular}



